\title{
SPATIAL ANALYSIS OF LAND COVER CHANGES IN EASTERN TIGRAY (ETHIOPIA) FROM 1965 TO 2007: ARE THERE SIGNS OF A FOREST TRANSITION?
}

\author{
Kassa Teka Belay, Anton Van Rompaey*, Jean Poesen, Simon Van Bruyssel, Jozef Deckers, Kassa Amare \\ Earth and Environmental Sciences, KU Leuven, Heverlee, Belgium
}

Received: 8 October 2013; Revised: 20 December 2013; Accepted: 21 December 2013

\begin{abstract}
This paper examines whether eastern Tigray is still in a phase of land degradation or if a trend of landscape greening has started. Hitherto, the land cover in five representative Tigray villages was mapped for three different periods: 1965, 1994, and 2007. These maps were based on the interpretation of aerial photographs and high-resolution satellite imagery in combination with field validation. The results show a strong decrease of the forest and bush land in favor of arable land and rangeland from 1965 to 1994. This trend is, however, slowed down and even reversed from 1994 onwards whereby some of the arable land and rangeland are abandoned allowing shrubs and bushes to regenerate. Household interviews and census data showed that the rural population number is still increasing. However, the productivity of the farming activities did not show a significant increase. The observed abandonment of marginal farm and rangeland is, therefore, made possible only through food aid and the import of food from other regions. Furthermore, policymakers stimulate land abandonment and landscape greening by establishing exclosures. Copyright @ 2014 John Wiley \& Sons, Ltd.
\end{abstract}

KEYWORDS: land cover change; land degradation; spatial analysis; Tigray; population growth; food aid; forest transition

\section{INTRODUCTION}

Landscapes in the highlands of eastern Tigray suffer from land degradation caused by a high and increasing population that dominantly lives from self-subsistence agriculture. According to estimates of the Central Statistical Agency of Ethiopia (CSA, 1994, 2008), the population number in eastern Tigray, which has an area of ca. $12,500 \mathrm{~km}^{2}$ increased from ca. 700,000 in 1965 to ca 1,500,000 in 2007. Statistics suggest that eastern Tigray is still at the beginning of a demographic transition with a decreasing mortality and an increasing annual population growth rate from $0.2 \%$ in 1965 to $3.0 \%$ in 2007. Removal of the natural vegetation for expansion of the arable fields and rangeland has led to increased soil losses and growing rock outcrops, which leads to nutrient depletion and a lowering of agricultural yields (Woldeamlak \& Stroosnijder, 2003; Mulugeta et al., 2005).

In response to these crises, national and local governments have put forward a set of measures to counteract land degradation. At the village level, exclosures were installed by local governments since 1994 to keep cattle out of certain areas (Descheemaeker et al., 2006; Balana et al., 2012). Remaining natural areas and forests were protected by prohibiting wood extraction and grazing (Descheemaeker et al., 2006; Balana et al., 2012). Mekuria \& Aynekulu (2011) evaluated the long-term effect of such exclosures

*Correspondence to: A. Van Rompaey, Physical and Regional Geography Research Group, KU Leuven, Celestijnenlaan 200E, B-3001 Leuven, Belgium. E-mail: anton.vanrompaey@ees.kuleuven.be on soil properties in the northern highlands of Ethiopia and reported a significant increase of total soil nitrogen and available phosphorus over time.

Plantations of eucalypt trees provide an alternative source of wood (Nyssen et al., 2004). Eucalypt trees were introduced in the surroundings of the capital Addis Ababa at the end of the 19th century. It took, however, more than 80 years before they appeared in the northern highlands from 1980 onwards following the land use policy of the Derg Regime (1975-1991). Despite their potential to slow down deforestation at a regional scale level, recent soil research showed that eucalypt trees may negatively affect the environment because they can cause the following: (i) a strong reduction of the water-table (Gindaba et al., 2004; Chanie et al., 2013); (ii) the increase of soil water repellency (Santos et al., 2013); (iii) a reduction of soil fertility due to an alteration of soil chemical properties (Leite et al., 2010) and a disturbance of the soil microbiology (Wu et al., 2013); and (iv) the long-term decrease of soil organic carbon (Fialho \& Zinn, 2012).

Water reservoirs were installed to collect and store runoff water (Haregeweyn et al., 2005; Balana et al., 2012). From 1994 to 2003, 54 large dams (Haregeweyn et al., 2006) each with an average water storage capacity of some 1-3.5 million cubic metres (Gebreyohannes et al., 2012) were constructed in Tigray. Following the 2002 drought year, small-scale household rainwater harvesting ponds have been subsidized by the regional government in the form of food-for-work programs. Simultaneously, the post-1991 government tried to increase the productivity of the agricultural practices by stimulating the adoption of new farming 
techniques such as the application of artificial fertilizers, the use of drought-resistant crop varieties, and conservation agriculture (Tigist et al., 2010; Tesfay et al., 2011).

If successful, these measures and developments should have led to a slowing down and eventually reversing of the ongoing land degradation in Tigray. At the landscape scale, this could result in a so-called forest transition, a shift from net deforestation to net reforestation or greening of the landscape (Lambin \& Meyfroidt, 2011). Such transition is often associated with both the biophysical environment and the socioeconomic status of the population. Mather \& Needle (1998) outlined a theoretical forest transition model, which suggests that as countries undergo a process of development, forest cover follows a U-shaped curve. Similar observations were reported by Cerdà (1997) for Southeastern Spain, Van Rompaey et al. (2002) for Belgium, Rudel et al. (2005) for Latin America, Meyfroidt \& Lambin (2009) for Vietnam, Zhou et al. (2009) for China, \& Redoa et al. (2012) for Central America.

Hitherto, forest transitions have been described in many parts of the world. For eastern Tigray, however, it is at present not clear whether a long-lasting degradation phase is slowed down and possibly reversed. A few local case studies (Ermyas et al., 2006; Alemayehu et al., 2009) suggested a decline of wooded shrub grassland and shrub grassland over the last 40 years, whereas other case studies in Tigray (Woldeamlak \& Stroosnijder, 2003; Girmay et al., 2010) reported an increase of shrub land during the last decades. A regional historical analysis based on repeated photography of landscapes in eastern Tigray (Munro et al., 2008; Nyssen et al., 2009b) suggested an overall landscape greening over the 20th century. These studies, however, do not reveal the possible driving factors of this greening. In order to develop and enforce a policy that reduces land degradation by stimulating landscape greening through land cover changes, it is important to obtain an insight into the ongoing land cover change processes and its driving factors. Therefore, this paper aims to address the following research questions:

(i) Is the landscape in eastern Tigray at present greening or degrading?

(ii) What land use conversions are causing the greening or degradation?

(iii) What are the drivers of these land use conversions: increasing agricultural productivity, food import, or policy?

To answer these questions, land cover change patterns from 1965 to present were mapped for five villages in contrasting agroecological settings in eastern Tigray. The observed trends were compared with local population dynamics, productivity of farming practices, and policy.

\section{MATERIALS AND METHODS}

\section{Study Area}

The study area is situated on the western shoulder of the Great Rift Valley with altitudes that range from 500 to $3050 \mathrm{~m}$ asl in the northeast of the Tigray province (Figure 1). The study area can be split up in three agroecological zones: lowland (less than $1500 \mathrm{~m}$ asl), midland (1500 to $2300 \mathrm{~m}$ asl), and highland (2300 to $3000 \mathrm{~m}$ asl) (Hagos et al., 1999). Eastern Tigray is characterized by a semi-arid climate with an average annual rainfall between 450 and $980 \mathrm{~mm}$. It has an estimated population of about 1.5 million, which corresponds to an average population density of 124 inhabitants per square kilometre. Population census data are only available for the years 1994 and 2007. The Central Statistical Agency of Ethiopia (CSA) proposes an exponential

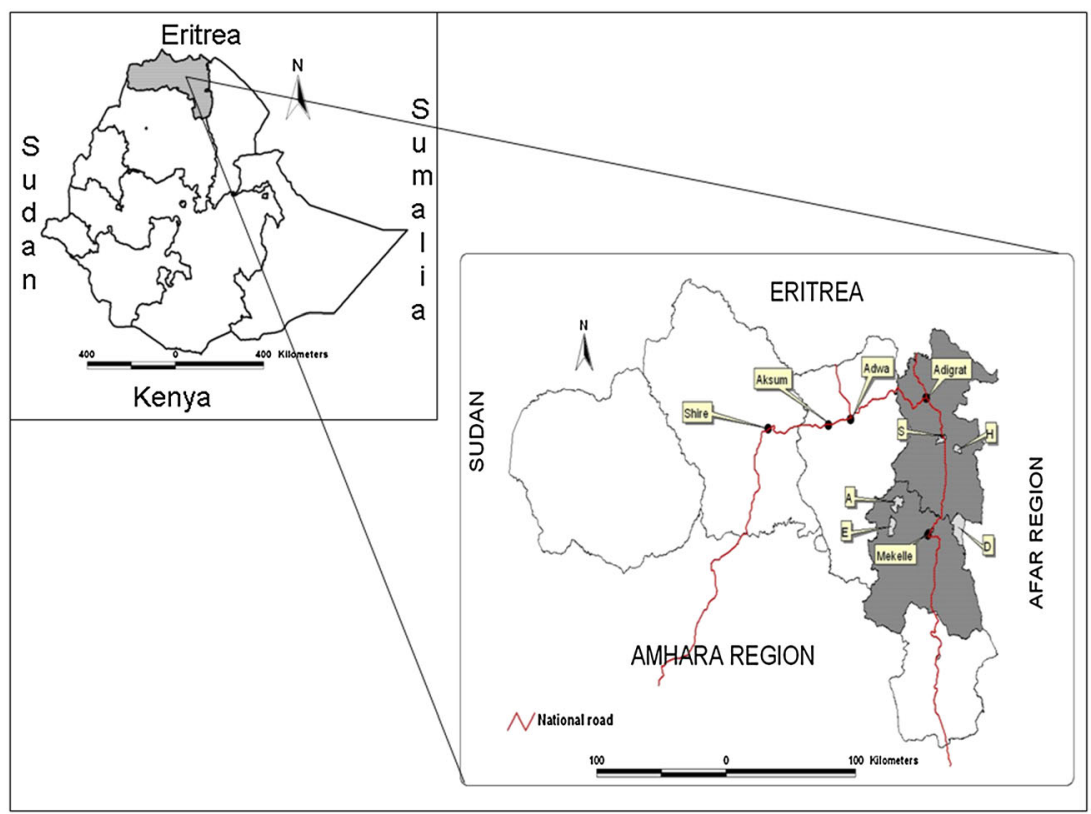

Figure 1. Location of the study area in Tigray (shaded) and the 5 selected villages (A=Aynimbrkekn, D=Dergajen, E=Endaselasie, H=Hadnet \& $\mathrm{S}=\mathrm{Sinkata})$. 
population growth model (Equation 1) to assess population numbers from 1965 to present.

$$
P_{\mathrm{t}}=\left(P_{1}\right) *\left(e^{r . z}\right)
$$

Where: $P_{\mathrm{t}}=$ the population in the target year, $P_{1}=$ the population in the launch year, $r=$ average annual growth rate, and $z=$ the number of years between the target year $\mathrm{t}$ and the launch year 1 .

Central Statistical Agency of Ethiopia assesses the average annual growth rate for the Tigray province at $0.2 \%$ from 1965 to 1984 , at $2.8 \%$ from 1985 to 1990 , and at $3.0 \%$ from 1990 to 1994. Starting from the census year 1994, the growth rate estimates of the CSA were used to assess the population number for each village in the year 1965 .

The dominant farming system is mixed farming with arable crop growing and livestock breeding. Major crops grown include Sorghum bicolor L., Eragrostis teff L., Zea mays L., Eleusine coracana (L.) Gaertn., Triticum aestivum L., and Hordeum vulgare L. Most farming households keep livestock (e.g., sheep, goat, and cattle), which are herded on rangeland during the growing season. After harvest, the livestock can graze the residues on arable land (Nyssen et al., 2009a).

The study sites are dominated by the bushy species of Acacia etbaica Schweinf. and Dodonaea angustifolia (L.) Jacq. along with occasional patches of eucalypt (Eucalyptus camaldulensis Dehnh and Eucalyptus globulus Labill.) and Acacia saligna (Labill.) H. Wendl, which were planted in the more degraded sites. In some area's Acacia species are tapped for gum arabic production (Lemenih et al., 2011).

\section{Study Methods}

Within the study area of eastern Tigray, the land cover change from 1965 to present was studied in detail for five

Table I. Identified land cover types

\begin{tabular}{ll} 
Land use type & \multicolumn{1}{c}{ Description } \\
\hline Arable land & $\begin{array}{l}\text { Annual and perennial crops }(>70 \% \text { of the land), frequently observed on level lands (plains, } \\
\text { plateaus, foot slopes, and valley floors) }\end{array}$
\end{tabular}

Bare land

Land devoid of vascular plants; composed of exposed rock, sand, and soil surface

Grass land

Open grassland/herb found in flat areas, grasses around the river banks in which water-table is at or near the surface

Built-up area

Residences, administrative buildings, small industrial, and trade enterprises.

Shrub land

Dominant vegetation lower than $1 \mathrm{~m}$, with a canopy cover below $50 \%$ but higher than $5 \%$

Bush land

Dominant vegetation lower than $3 \mathrm{~m}$ but higher than $1 \mathrm{~m}$ with a canopy cover above $15 \%$, or dominant vegetation below $1 \mathrm{~m}$ with a canopy cover above $50 \%$

Forest land

Patches with a canopy cover over 50\%. These can be remnant of high natural forest, found in small patches around churches, on steep slopes and less populated areas or recent eucalypt plantations.

Water body

Any type of surface water 
selected villages (Figure 1) representing three agroecological zones: Hadnet and Aynimbrkekn (highland), Sinkata and Dergajen (midland), and Endaselasie (lowland). For each of the selected villages, the land cover was mapped in detail at 3 years, that is, 1965, 1994, and 2007. For the classification of land cover classes, the typology proposed by BoANR (2001) was followed (Table I).

The land cover maps for 1965 and 1994 were derived from scanned aerial photographs at a scale of 1:50,000 (Ethiopian Mapping Agency). The land cover map for 2007 was derived from very high-resolution satellite imagery, IKONOS, of $4 \mathrm{~m} \times 4 \mathrm{~m}$ resolution. The aerial photographs and the satellite images were georeferenced and orthorectified on the basis of ground control points. For each image, a few hundred-ground control points (known objects such as old churches, farmhouses, river crossings, and road crossings) were recorded in the field with the help of global positioning system.

For each of the villages, representative transects of a few kilometres throughout various land cover types were walked and recorded with global positioning system during the rainy season of 2009 and 2010 . Next, the recorded transects were plotted on a true color composite of the satellite images of 2007. This allowed identifying and delineating homogeneous land cover patches for each village. Finally, the land cover maps for 1994 and 1965 were constructed by identifying the land cover type visually on the aerial photographs for each patch that was delineated on the satellite imagery of 2007. The three map series allowed to assess the temporal and spatial evolution of the different land cover types in the selected villages. The percent changes in land cover (Table II) were calculated following Equation 2:

$$
\text { Change }_{L U x}(\%)=\frac{L U_{X y 2}-L U_{X y 1}}{L U_{X y 1}} * 100
$$

Where: $L U_{X} y 1$ is area of land cover type $x$ in year 1 and $L U_{X y 2}$ is area of land cover type $x$ in year 2 .

To explain the observed land cover change, the following data were collected for each village: (i) the demographic evolution was reconstructed from census data of 1994 and 2007 and extrapolation models (Equation 1) and (ii) evolution of agricultural productivity levels was derived from interviews with farming household heads. The change in area of arable land, shrub land, bush land, and forest was correlated with the change in population.

In the years 2009 and 2010, 140 household heads were interviewed. The household heads were typically elderly men and women over 65 years and were identified with the help of the village administrator and agricultural development agents in each village. Most rural people are not familiar with the common (western) era but situate events in time on the basis of a major event calendar, which is a sequence of important events that happened in a given village such as the death of a known local leader, the fight between local feudal leaders, locust infestation, election of political leaders, and others. Before starting the interviews in a village, a group meeting with circa ten key informants in each village was organized to develop a village-specific major event calendar. When the household heads were interviewed, the major event calendar could be used to reconstruct the chronology of the story told and to date the events along the common era. The interviews with the household were semi-structured and aimed to obtain an insight in general way of living between 1965 and present.

On the basis of the historical maps and the interview data for each village $(v)$ and for each period, a per capita grain production was assessed as follows (Equation 3):

$$
P C P_{v}=\frac{A_{v} * G_{v}}{P_{V}}
$$

Where: $\quad \mathrm{PCP}_{v}$ : per capita grain production for village $v$ in kilogram per year per person

$A_{v}$ : the area of arable land in each village (in hectare)

$G_{v}$ : the grain crop productivity (in kilogram per hectare per year)

$P_{v}$ : the village population

\section{RESULTS AND DISCUSSION}

As an example, Figure 2 shows the land cover for 1965, 1994, and 2007 for Hadnet, which is one of the five selected villages. The area under arable land in Hadnet increased significantly in the period between 1965 and 1994 whereas the area with bush land and forest land has clearly decreased. This trend is reversed between 1994 and 2007 with a slight

\begin{tabular}{|c|c|c|c|c|}
\hline & \multicolumn{2}{|c|}{ Area change $\left(\mathrm{km}^{2}\right)$} & \multicolumn{2}{|c|}{ Area change $(\%)$} \\
\hline & 1965-1994 & 1994-2007 & 1965-1994 & 1994-2007 \\
\hline Arable land & 23.05 & -2.59 & 8.44 & -0.95 \\
\hline Bare land & -7.35 & -0.02 & -2.69 & -0.01 \\
\hline Grass land & -1.43 & -0.27 & -0.52 & -0.10 \\
\hline Built-up area & 2.15 & 0.44 & 0.79 & 0.16 \\
\hline Shrub land & 37.44 & 1.36 & 13.71 & 0.50 \\
\hline Bush land & -46.55 & 0.79 & -17.04 & 0.29 \\
\hline Forest land & -7.86 & 0.06 & -2.88 & 0.02 \\
\hline Water body & 0.56 & 0.23 & 0.20 & 0.08 \\
\hline
\end{tabular}

Table II. Land cover change from 1965 to 2007 (for the five studied villages) 

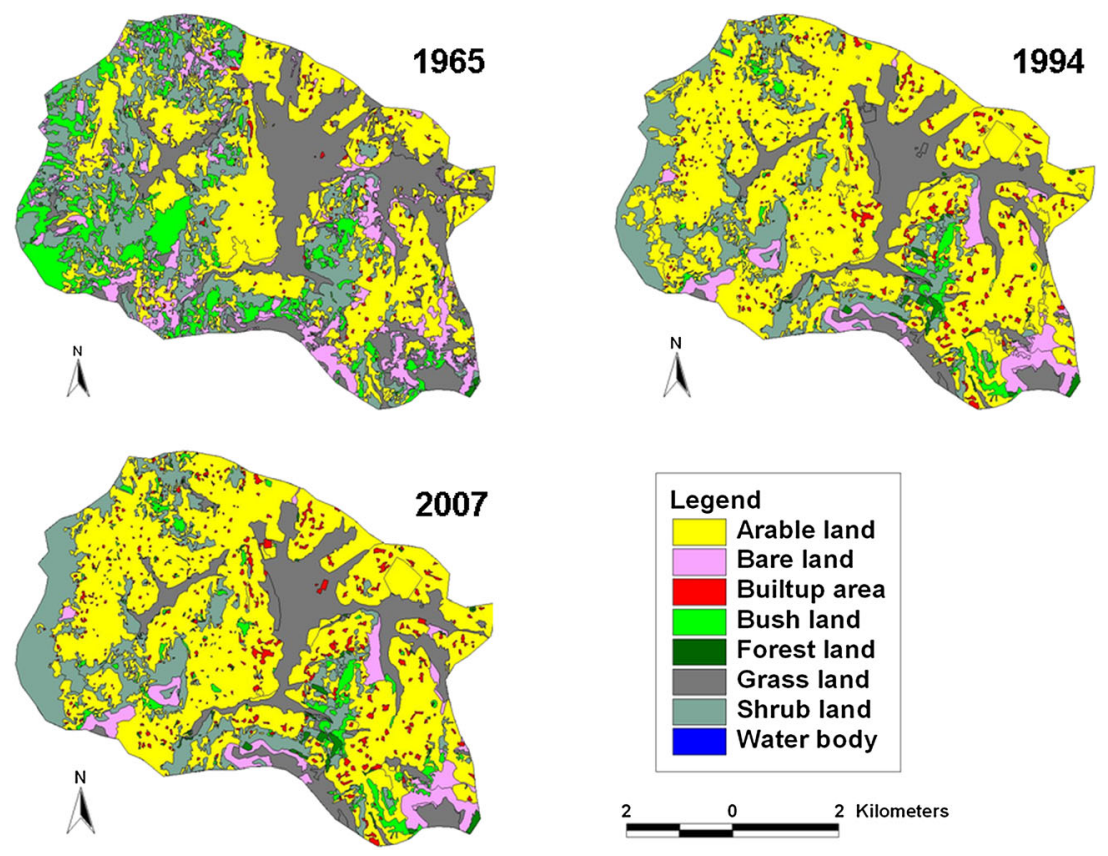

Figure 2. Land cover maps. This figure is available in colour online at wileyonlinelibrary.com/journal/ldr.

decrease of the area of arable land and a moderate increase of shrub and bush lands.

The average trend of the different land cover classes in the five selected villages is shown in Table II. The figures suggest a degreening of eastern Tigray from 1965 to 1994. After 1994, the trend is reversed with an increase in the area of shrub land and bush land. The area of arable land shows an inverse evolution with $8.4 \%$ overall increase in the first phase (1965-1994) but about $1 \%$ reduction in the second phase (1994-2007). In the period 1994-2007, the area of arable land decreased partly because of conversions from arable land to built-up area to house the growing population and partly because unfavorable and degraded fields were abandoned. These findings are in line with the regional trends reported by de Mûelenaere et al. (2012) who compared LANDSAT imagery for the years 1972, 1984, and
2000. Table III lists the observed land cover trends for each of the five selected villages separately and shows that the overall trend is not valid for all villages. In Sinkata, the greening of the landscape already started between 1965 and 1994 with an increase of the forest area, whereas in Dergajen, the forest cover is still decreasing.

To obtain an insight into possible drivers of this transition, the observed land cover changes were compared with changes in population number. Table IV shows the population number in the five selected villages in between 1965 and 2007. The data showed a wide variation in the population distribution within the study villages. The population growth rate in three out of the five villages is still above the regional (2.5\%) and national (2.6\%) rates (CSA, 2008).

In Table $\mathrm{V}$, population growth rates are correlated with the area of each land cover type. This table shows a positive

Table III. Land cover categories (in \%) in the five selected villages for the years 1965, 1994, and 2007

\begin{tabular}{|c|c|c|c|c|c|c|c|c|c|}
\hline \multirow[b]{2}{*}{ Village } & \multirow[b]{2}{*}{ Year } & \multicolumn{8}{|c|}{ Land cover area (in \% of total village area) } \\
\hline & & Arable & Bare & Grass & Built up & Shrub & Bush & Forest & Water \\
\hline \multirow[t]{3}{*}{ Hadnet } & 1965 & 34.0 & 10.0 & 21.8 & 1.0 & 22.5 & 10.6 & 0.2 & 0.0 \\
\hline & 1994 & 58.3 & 4.9 & 15.4 & 2.9 & 15.1 & 2.5 & 1.0 & 0.0 \\
\hline & 2007 & 55.8 & 4.8 & 15.2 & 3.3 & 16.6 & 3.2 & 1.1 & 0.0 \\
\hline \multirow[t]{3}{*}{ Aynimbrkekn } & 1965 & 52.9 & 2.7 & 1.9 & 1.5 & 38.2 & 2.5 & 0.2 & 0.1 \\
\hline & 1994 & 55.1 & 2.5 & 1.6 & 1.5 & 38.0 & 0.9 & 0.2 & 0.1 \\
\hline & 2007 & 54.3 & 2.5 & 1.5 & 1.6 & 38.7 & 0.9 & 0.2 & 0.2 \\
\hline \multirow[t]{3}{*}{ Dergajen } & 1965 & 37.1 & 3.3 & 3.2 & 0.8 & 25.1 & 24.4 & 6.1 & 0.0 \\
\hline & 1994 & 42.7 & 0.2 & 3.8 & 1.4 & 50.7 & 0.4 & 0.3 & 0.5 \\
\hline & 2007 & 41.6 & 0.2 & 3.7 & 1.5 & 51.6 & 0.4 & 0.3 & 0.6 \\
\hline \multirow[t]{3}{*}{ Sinkata } & 1965 & 56.1 & 12.1 & 15.6 & 1.5 & 9.3 & 5.0 & 0.4 & 0.0 \\
\hline & 1994 & 67.2 & 4.9 & 14.6 & 5.0 & 6.1 & 1.3 & 0.9 & 0.0 \\
\hline & 2007 & 66.2 & 4.9 & 14.6 & 5.5 & 5.8 & 1.9 & 0.9 & 0.1 \\
\hline \multirow[t]{3}{*}{ Endaselasie } & 1965 & 21.0 & 10 & 0.0 & 0.4 & 34.2 & 37.3 & 5.8 & 0.3 \\
\hline & 1994 & 33.1 & 0.1 & 0.1 & 0.5 & 59.7 & 4.3 & 1.9 & 0.3 \\
\hline & 2007 & 33.2 & 0.1 & 0.0 & 0.5 & 59.0 & 5.0 & 1.9 & 0.3 \\
\hline
\end{tabular}




\section{K. T. BELAY ET AL.}

Table IV. Population and its growth rate at each of the five studied villages

\begin{tabular}{|c|c|c|c|c|c|c|}
\hline \multirow[b]{2}{*}{ Villages } & \multirow[b]{2}{*}{ Area $\left(\mathrm{km}^{2}\right)$} & \multicolumn{3}{|c|}{ Population number } & \multicolumn{2}{|c|}{ Annual growth rate $(\%)$} \\
\hline & & 1965 & 1994 & 2007 & 1965-1994 & 1994-2007 \\
\hline Aynimbrkekn & 61.1 & 11,001 & 11,059 & 11,126 & 0.02 & 0.05 \\
\hline Dergajen & 106.9 & 4726 & 6489 & 9524 & 1.09 & 2.95 \\
\hline Endaselasie & 50.9 & 1290 & 2236 & 4348 & 1.90 & 5.12 \\
\hline Hadnet & 26.4 & 3749 & 5097 & 7396 & 1.06 & 2.86 \\
\hline Sinkata & 27.9 & 3098 & 3953 & 5312 & 0.84 & 2.27 \\
\hline
\end{tabular}

correlation $(r=+0.67)$ between population growth and growth of the arable land area between 1965 and 1994. After 1994, this correlation is no longer present. A weaker positive correlation $(r=+0.51)$ could be detected between the population growth and the increase in shrub land area for the period 1965-1994. After 1994, no correlation could be found. Population growth is negatively correlated $(r=-0.71)$ with the bush land area between 1965 and 1994. After 1994, there is a slight positive correlation $(r=+0.1)$. For none of the periods, a significant correlation could be found between population growth and change in forest area. This corresponds well with the study of Geist \& Lambin (2002) and Sloan (2008) in which population alone predicts afforestation poorly. Villages with a high population growth experienced a strong decline in the bush land area in favor of arable land and shrub land. These bush land conversions were necessary to feed the growing population in a system of self-subsistence agriculture. Arable fields were established on the most suitable shrub and bush lands whereas the more remote and unfertile bush lands were used for grazing. The land degradation from 1965 to 1994 could be considered as the end of the declining limb of a U-shaped forest transition curve whereby deforestation is driven by population growth as described by Wright \& Muller-Landau (2006).

One would expect that the area of forest would show a similar evolution over time as the area of bush land. The fact that no correlation between population growth and forest area declines before 1994 can be explained by the fact that the major forest clearing in eastern Tigray took place before 1965. Only a limited number of patches remained afterwards. Overall, a decline of the forest area could be observed between 1965 and 1994, but no correlation could be found because in two villages (Sinkata and Aynimbrkekn) eucalypt trees were introduced in the early 1980s resulting in an increase of the forest area. Originally, the eucalypt trees were planted by government agencies to fight soil degradation. Because of increasing timber, farmers also began to plant eucalypt trees around their houses so as to increase their income. This planting of trees is very small in absolute area but significant in relative terms if compared with the existing area of forest.

In the period after 1994, the correlation between population growth and landscape degradation is no longer present. Despite an even increased population growth, a modest landscape greening could be observed with conversions from arable land to shrub land and from shrub land to bush land. This decoupling could be related to the following: (i) an abandonment of the self-subsistence food production system whereby non-farming incomes are used to buy imported food or (ii) the result of a land management policy stimulating soil and water conservation and landscape greening by the installation of exclosures (Descheemaeker et al., 2006) and eucalypt plantations (Nyssen et al., 2004).

Table VI shows an assessment of the average yields per hectare (ha) for the different crops, which were derived from

Table V. Population growth rate versus change in land cover

\begin{tabular}{|c|c|c|c|c|c|c|c|c|c|}
\hline Villages & Population & Arable & Bush & Grass & Bare & Built up & Shrub & Water & Forest \\
\hline & \multicolumn{9}{|c|}{ Change (\%) between 1965 and 1994} \\
\hline Sinkata & 27.6 & 19.9 & -73.0 & -6.3 & -59.8 & 224.0 & -34.1 & - & 116.4 \\
\hline Hadnet & 36.0 & 71.2 & -76.0 & -29.3 & -51.0 & 196.8 & -32.0 & - & 331.1 \\
\hline Endaselasie & 73.3 & 57.5 & -88.0 & 0.0 & -85.9 & 26.0 & 74.7 & - & -67.5 \\
\hline Dergajen & 37.3 & 15.2 & -98.0 & 19.2 & -95.1 & 66.6 & 102.1 & - & -95.2 \\
\hline \multirow[t]{3}{*}{ Aynimbrkekn } & 0.5 & 4.2 & -60.0 & -14.3 & -8.6 & 3.2 & -0.6 & - & -0.1 \\
\hline & $\mathbf{R}$ & 0.67 & -0.71 & 0.30 & -0.80 & -0.04 & 0.51 & - & -0.18 \\
\hline & \multicolumn{9}{|c|}{ Change (\%) between 1994 and 2007} \\
\hline Sinkata & 34.4 & -1.0 & 49.7 & -0.2 & 0.9 & 10.6 & -5.4 & 60506.1 & 5.0 \\
\hline Hadnet & 45.1 & -4.3 & 31.8 & -1.2 & -0.9 & 13.4 & 9.8 & 5444.8 & 7.8 \\
\hline Endaselasie & 94.5 & 0.0 & 17.2 & -100.0 & 0.0 & 7.6 & -1.2 & 9.9 & 0.0 \\
\hline Dergajen & 46.8 & -2.6 & 4.4 & -2.3 & -3.3 & 8.5 & 1.8 & 24.6 & 10.3 \\
\hline \multirow[t]{2}{*}{ Aynimbrkekn } & 0.6 & -1.4 & 3.2 & -8.6 & -0.8 & 4.8 & 1.9 & 61.0 & -0.2 \\
\hline & $\mathbf{R}$ & 0.27 & 0.10 & -0.79 & 0.07 & 0.22 & -0.11 & -0.17 & -0.01 \\
\hline
\end{tabular}


Table VI. Land productivity in the five selected villages (- indicates no data available)

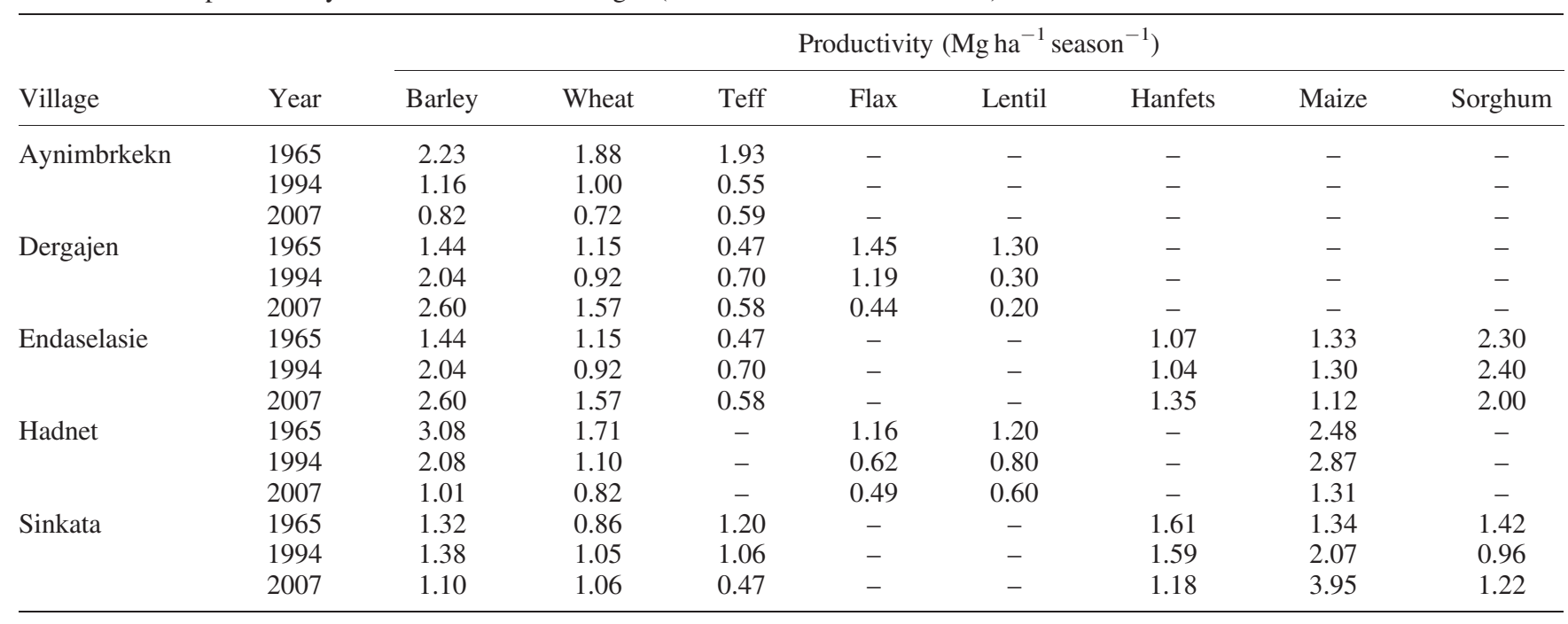

the same household interviews. In general, the productivity of the farming practices is low with an average grain yield of about $1 \mathrm{Mgha}^{-1} \mathrm{y}^{-1}$. This is in agreement with a national-scale agricultural sample survey results from 1994 that showed the average yield of all crops grown in Ethiopia was about $1 \mathrm{Mg} \mathrm{ha}^{-1}$ (CSA, 1995). Moreover, the results show in general a decrease in the farming productivity for most of the crops in spite of many government programs that aimed to introduce soil and water conservation measures and more productive farming techniques. Next, the crop productivity estimates were combined with the land cover maps in order to assess the total crop production per village and the per capita food availability using Equation 3.

The assessments of the annual per capita food availability are shown in Table VII. The numbers are average approximations and assume that no food crops were exported. This assumption is realistic because the interviews indicate that none of the households in the selected villages gain a significant income from selling their own crops. In most cases, the limited non-food expenditure of the households was obtained from off-farm jobs and support programs. The results (Table VII) show a decrease of the per capita food production in all the villages over the studied period, 1965-2007, which is the combined effect of a decrease in agricultural productivity (Table VI) and a population increase (Table IV). In 2007, four out of five villages produced enough grain food to feed the local population. However, these numbers do not take into account the fact that part of the harvest needs to be sold on the market to buy non-food items such as clothes, equipment, and kerosene. Therefore, in reality, many households are strongly dependent on food aid programs. Similar studies at national level (Clay et al., 1999) have also shown a decline in per capita food production since the early 1970 s, which has made the country dependent on commercial imports of food and food aid.

The observed lowering farming productivity in the study area is in contrast with the overall increase of farming productivity from 1994 onwards for the whole of Ethiopia as reported by the FAO (FAOSTAT, 2012). Reasons for the observed lowering productivity in eastern Tigray are manyfold. First, there is a lack of financial means for investment in fertilizers and modern technologies (Byerlee et al., 2007). Second, most households cultivate a total area of less than 1 ha often split up in many different plots spread out over the village, which makes farming management unprofitable (Jayne et al., 2002). Between 1960 and 1990, the population size of Ethiopia doubled, while per capita landholding shrunk from 0.3 to 0.1 ha and per capita food output collapsed by $41 \%$ (Befekadu \& Berhanu, 2000). Third, historical land degradation has lowered the fertility of many farmlands. Various authors have reported high to very high erosion rates on arable land in Tigray. Hurni (1993) showed a $42-\mathrm{Mg} \mathrm{ha}^{-1} \mathrm{y}^{-1}$ average soil loss rate on croplands and a maximum rate of up to $300 \mathrm{Mgha}^{-1} \mathrm{y}^{-1}$ in

Table VII. Annual per capita grain food production, surplus, and deficit in the selected villages computed on the basis of a minimum calorie requirement of $2100 \mathrm{cal}=225 \mathrm{~kg}$ grain person ${ }^{-1}$ year $^{-1}($ MEDAC, 1999)

\begin{tabular}{|c|c|c|c|c|c|c|c|}
\hline \multirow[b]{2}{*}{ Village } & \multicolumn{3}{|c|}{ Per capita grain food production $(\mathrm{kg})$} & \multicolumn{3}{|c|}{ Per capita surplus $(+)$ or deficit $(-)(\mathrm{kg})$} & \multirow{2}{*}{$\begin{array}{c}\text { Per capita } \\
\text { food aid } \\
(\mathrm{kg}) \text { in } 2007\end{array}$} \\
\hline & 1965 & 1994 & 2007 & 1965 & 1994 & 2007 & \\
\hline Aynimbrkekn & 532 & 279 & 242 & +307 & +54 & +17 & 51 \\
\hline Dergajen & 1056 & 722 & 664 & +831 & +497 & +439 & 79 \\
\hline Endaselasie & 944 & 876 & 604 & +719 & +651 & +379 & 41 \\
\hline Hadnet & 538 & 490 & 175 & +313 & +265 & -50 & 59 \\
\hline Sinkata & 692 & 585 & 381 & +467 & +360 & +156 & 76 \\
\hline
\end{tabular}


individual fields. Haregeweyn et al. (2013) reported areaspecific sediment yields derived from sedimentation rates in 12 reservoirs in the eastern part of Tigray between 1.9 and $18.2 \mathrm{Mg} \mathrm{ha}^{-1} \mathrm{y}^{-1}$. Adimassu et al. (2013) evaluated the effect of stone bunds on runoff and losses of soil and nutrients and crop yield for barley fields in central Ethiopia and came to the conclusion that stone bunds can reduce the losses of soil and nutrients with $47 \%$ but the reported losses are still in the order of $25 \mathrm{Mgha}^{-1} \mathrm{y}^{-1}$. Woldeamlak \& Stroosnijder (2003), Mulugeta et al., (2005), \& Aweke et al., (2013) were able to show that this long-term soil erosion led to a decrease of the soil fertility in the northern Ethiopian highlands because of the loss of soil organic carbon, nitrogen, and exchangeable phosphorus. Moreover, interviewees revealed poor manure availability due to a reduced livestock and dung collecting as an alternative for fuel wood as a cause for the reduced productivity. The traditional practices of soil fertility replenishment such as fallowing, the use of cattle dung, and crop residues have now largely been abandoned. This is because of the land shortage as well as the use of dung and crop residues for domestic energy production purposes as the forests and trees have become very scarce. Scarcity of cultivable land due to growing populations and land degradation hinders peasants from leaving fallow land to recuperate its fertility (Tesfay et al., 2011).

To evaluate whether the local population is able to feed itself, a food surplus or deficit was calculated using a procedure proposed by Ministry of Economic Development and Cooperation (1999). Ministry of Economic Development and Cooperation assumes that a person requires $2100 \mathrm{cal} /$ day, which requires $225 \mathrm{~kg}$ grain per person per year. The results (Table VII) show that in 1965, the crop production in the villages was sufficient to feed the double of its population and the villages were, therefore, net exporters of grain. Despite an increase of the area of arable land, most villages now produce less food to feed the local population. Not being self-subsistent is not necessarily a problem if a sufficient income is generated from off-farm jobs that allow to buy imported food products. Most interviewees, however, received only a very limited or no income from off-farm jobs. The limited engagement in off-farm jobs can partly be explained by the fact that all villagers continue to be farmer and consider the off-farm jobs as a sort of insurance that provides an additional income in periods with low rainfall (Befekadu \& Berhanu, 2000).

An important driving factor in the household economy and the related land cover changes at village level are food imports through national and international support programs. Food aid in the study area has taken two major forms (Jayne et al., 2002): free distribution, which is sometimes referred to as emergency or relief distribution, and food for work, sometimes referred to as development food aid. After the devastating famine of 1973/1974, the Ethiopian Ministry of Agriculture began to use relief food aid for undertaking work in drought-affected areas in collaboration with the World Food Program. The Relief Society of Tigray was established in 1978 as the social welfare and development arm of the Tigray Peoples' Liberation Front. It has been involved in providing food aid to drought victims and war refugees, typically as free food often supplied to displaced persons, since that time. After the 1984/1985 famine and as increasingly large areas of the region came under the control of the Tigray Peoples' Liberation Front and refugees began returning from Sudan, Relief Society of Tigray's approach to food aid shifted to community-oriented rehabilitation. USAID/Ethiopia began providing relief and development resources in the mid-1980s. The present USAID regular food aid program, called the Integrated Agricultural Development Program, began in 1992 with the principle that relief and rehabilitation had to be integrated with development and all those capable of working would be encouraged to take part (Catterson et al., 1994).

Many farmers in the studied villages, currently, have the opportunity to be involved in development food aid through development programs such as Food for Work and Productive Safety Net Project. These development programs are supported and implemented by international donor organizations in order to fight food insecurity. In times of food shortages, because of drought and crop failure, farming households receive food from the program (Andersson et al., 2009). In return, farming households have to invest a specific amount of labor in public works such as maintenance of stone bunds and other soil and water conservation structures, the rehabilitation of gullies (Yitbarek et al., 2012), the digging of common water wells, and the construction of micro-dams and water ponds. The Productive Safety Net Project is a public program (implemented by USAID and other donors), which is intended to enable households an uninterrupted consumption without being forced to sell productive assets in order to overcome food shortages. It differs from previous food-for-work programs in that it focuses continuously on a number of selected households over several years with the explicit objective to phase out (Andersson et al., 2009).

Since 1989, progressive terracing with stone bunds supported by relief food aid was undertaken by all the able bodied farmers throughout the region (Betru \& Wickrema, 2010). Much of the stone bunding and terracing common in Tigray was established as a means for distributing food aid and with the hope of achieving environmental rehabilitation (Catterson et al., 1994). According to Betru and Wickrema (2010), over 225,000 ha of the Tigray province has been so treated. These development programs have also acted as an important alternative source of income. An assessment of the additional average amount of grain per village in the year 2007 (in kilogram grain per capita) through development food aid is shown in Table VII. The results show that the grain import through food aid programs is a significant contribution to the local food availability. In the case of Hadnet village, the support is even necessary to compensate for the average deficit.

The landscape greening that was observed in the study area from 1994 onwards is, therefore, not driven by an 
economic development pathway as described by Rudel et al. (2005) because the agricultural productivity and the total food production in the selected villages decreased also after 1994. Because of policy measures such as the installation of exclosures and forest protection rules, the landscape deforestation has stopped. The abandonment of farmland is, however, only made possible because of substantial food imports from international support programs. The landscape greening in eastern Tigray could, therefore, be considered as the beginning of the rising limb of a forest transition driven by environmental degradation and policy interventions. After decades of soil degradation, crop yields are so low that in combination with an erratic climate, frequent famines would occur if no food aid programs were present.

\section{CONCLUSIONS}

The results from this study show that after decades of deforestation, a relatively recent re-greening transition has started in eastern Tigray with a decrease of arable land in favor of shrub and bush lands. This greening could, however, not be explained by an increase of the agricultural productivity. On the contrary, it was observed that many local farming households produced less and many others are dependent on food aid. The abandonment of farmland is, however, only made possible because of substantial food imports from international support programs. Because of policy measures such as the installation of exclosures and forest protection rules, the landscape deforestation has stopped.

The landscape greening in eastern Tigray could, therefore, be considered as the beginning of the rising limb of a forest transition driven by environmental degradation and policy interventions. After decades of soil degradation, crop yields are so low that in combination with an erratic climate, frequent famines would occur if no food aid programs were present.

\section{ACKNOWLEDGEMENTS}

The authors would like to thank the VLIR-UOS-Mekelle University Inter University Cooperation for the financial and logistic support for this study. We also would like to thank the farmers, agricultural development agents, and local administrators of the study villages for their assistance during the field work. The review made by the two referees and the editor is greatly acknowledged as their comments and suggestions significantly improved an earlier version of this manuscript.

\section{REFERENCES}

Adimassu Z, Mekonnen K, Yirga C, Kessler A. 2013. Effects of stone bunds on runoff, soil and nutrient losses, and crop yield in the central highland of Ethiopia. Land Degradation \& Development. DOI: 10.1002/ldr. 2182

Alemayehu F, Taha N, Nyssen J, Girma A, Zenebe A, Mintesinot B, Deckers S, Poesen J. 2009. The impacts of watershed management on land use and land cover dynamics in eastern Tigray (Ethiopia). Resources, Conservation and Recycling 53: 192-198.

Andersson C, Mekonnen A, Stage J. 2009. Impacts of the productive safety net program in Ethiopia on livestock and tree holdings of rural households. Environment for Development, Discussion Paper Series, EfD DP 09-05.

Aweke MG, Singh BR, Lal R. 2013. Organic carbon and nitrogen associated with soil aggregates and particle sizes under different land uses in Tigray, northern Ethiopia. Land Degradation \& Development. doi: 10.1002/ldr.2261

Balana BB, Muys B, Haregeweyn N, Descheemaeker K, Deckers J, Poesen J, Nyssen J, Mathijs E. 2012. Cost benefit analysis of soil and water conservation measure: the case of exclosures in northern Ethiopia. Forest Policy and Economics 16: 27-36.

Befekadu D, Berhanu N. 2000. Annual report on the Ethiopian economy. Ethiopian Economic Association, Vol. I. 1999/2000. Addis Ababa, Ethiopia.

Betru N, Wickrema S. 2010. Disaster risk reduction: experience from the MERET project in Ethiopia. In: FAO, 2010. Revolution: From Food Aid to Food Assistance. Innovations in Overcoming Hunger. Pp 139-156.

BoANR. 2001. Land use and land cover of Tigray. Bureau of Agriculture and Natural Resources, Land Use Planning and Regulatory Division, Mekelle, Tigray, Ethiopia; 213.

Byerlee D, Spielman DJ, Alemu D, Gautam M. 2007. Policies to promote cereal intensification in Ethiopia: a review of evidence and experience. International Food Policy Research Institute, discussion paper, no. 00707. IFPRI: Washington DC.

Catterson TM, Buccowich M, Helin W. 1994. Natural Resources Management and Title II Food Aid: an evaluation. A Report Submitted to USAID/Ethiopia.

Cerdà, A. 1997. Soil erosion after land abandonment in a semiarid environment of Southeastern Spain. Arid Soil Research and Rehabilitation 11 $163-176$.

Chanie T, Collick AS, Adgo E, Johannes CL, Steenhuis TS. 2013. Eco-hydrological impacts of eucalyptus in the semi humid Ethiopian Highlands: the Lake Tana Plain. J. Hydrol. Hydromech. 61: 21-29.

Clay D, Molla D, Habtewold D. 1999. Food aid targeting in Ethiopia: a study of who needs it and who gets it. Food Policy 24: 391-409

CSA. 1994. The 1994 population and housing census of Ethiopia. Results for Tigray region. Central Statistical Agency: Addis Ababa, Ethiopia.

CSA. 1995. Agricultural sample survey for 1994/95. Report on Area and Production for Major Crops. Statistical Bulletin 132. Central Statistical Agency: Addis Ababa.

CSA. 2008. Summary and statistical report of the 2007 population and housing census results. Population size by age and sex. Central Statistical Agency of Ethiopia: Addis Ababa.

Descheemaeker K, Nyssen J, Rossi J, Poesen J, M Haile, Moeyersons J, Deckers J. 2006. Sediment deposition and pedogenesis in exclosures in the Tigray highlands, Ethiopia. Geoderma 132: 291-314.

Ermyas A, Emiru B, Zelday W, Nigussu B. 2006. Monitoring and evaluating land use/land cover changes using participatory geographic information system (PGIS) tools: a case study of Begasheka watershed, Tigray, Ethiopia. The Electronical Journal of Information Systems in Developing Countries 25: 1-10.

FAOSTAT. 2012. Faostat.fao.org

Fialho RC, Zinn, YL. 2012. Changes in soil organic carbon under eucalyptus plantations in Brazil: a comparative analysis. Land Degradation \& Development. doi: 10.1002/ldr.2158.

Gebreyohannes G, Nyssen J, Poesen J, Bauer H, Merckx R, Haile M, Deckers J. 2012. Land reclamation using reservoir sediments in Tigray, northern Ethiopia. Soil Use and Management 28: 113-119.

Geist H, Lambin EF. 2002. Proximate causes and underlying driving forces of tropical deforestation. BioScience 52: 143-50.

Gindaba J, Rozanov A, Negash L. 2004. Response of seedlings of two eucalyptus and three deciduous tree species from Ethiopia to severe water stress. Forest Ecology and Management 201: 119-129.

Girmay G, Singh BR, Dick O. 2010. Land use changes and their impacts on soil degradation and surface runoff of two catchments of northern Ethiopia. Acta Agriculturae Scandinavica Section B - Soil and Plant Science 60: 211-226.

Hagos F, Pender J, Gebresselassie N. 1999. Land degradation in the highlands of Tigray and strategies for sustainable land management. Socioeconomic and policy Research Working paper No. 25: International Livestock Research Institute. 


\section{K. T. BELAY ET AL.}

Haregeweyn N, Poesen J, Nyssen J, Verstraeten G, de Vente J, Govers G, Deckers S, Moeyersons J. 2005. Specific sediment yield in TigrayNorthem Ethiopia: assessment and semi-quantitative modeling. Geomorphology 69: 315-331.

Haregeweyn N, Poesen J, Nyssen J, De Wit J, Haile H, Govers G, Deckers S. 2006. Reservoirs in Tigray (northern Ethiopia): characteristics and sediment deposition problems. Land Degradation \& Development 17: 211-230.

Haregeweyn N, Poesen J, Verstraeten G, Govers G, de Vente J, Nyssen, DJ, Moeyersons J. 2013. The performance of a spatially distributed soil erosion and sediment delivery model (WATEM/ SEDEM) in northern Ethiopia. Land Degradation \& Development 24(2): 188-204.

Hurni H. 1993. Land degradation, famines and resource scenarios in Ethiopia. In World soil erosion and conservation, D Pimental (ed). Cambridge University Press: Cambridge; 27-62.

Jayne TS, Strauss J, Yamano T, D Molla. 2002. Targeting of food aid in rural Ethiopia: chronic need or inertia? Journal of Development Economics 68: 247-288.

Lambin EF, Meyfroidt P. 2011. Global land use change, economic globalization and the looming land scarcity. PNAS 108: 3465-3472.

Leite FP, Silva IR, Novais RF, de Barros NF, Neves JCL. 2010. Alterations of soil chemical properties by eucalyptus cultivation in five regions in the Rio Doce Valley. R. Bras. Ci. Solo 34: 821-831.

Lemenih M, Wiersum KF, Woldeamanuel T, Bongers F. 2011. Diversity and dynamics of management of gum and resin resources in Ethiopia: a trade-off between domestication and degradation. Land Degradation \& Development. doi: 10.1002/ldr.1153

Mather A, Needle C. 1998. The forest transition: a theoretical basis. Area 30: $117-124$.

Mekuria W, Aynekulu E. 2011. Exclosure land management for restoration of the degraded communal grazing land in northern Ethiopia. Land Degradation \& Development. doi: 10.1002/ldr.1146

Meyfroidt P, Lambin EF. 2009. Forest transition in Vietnam and displacement of deforestation abroad. Proceedings of the National Academy of Sciences of the States of America 106: 16139-16144.

Ministry of Economic Development and Cooperation (MEDAC). 1999. Survey of Ethiopian economy. Addis Ababa, Ethiopia.

de Mûelenaere S, Frankl A, Haile M, Poesen J, Deckers J, Munro N, Veraverbeke S, Nyssen J. 2012. Historical landscape photographs for calibration of LANDSAT land use/cover in the northern Ethiopian highlands. Land Degradation \& Development. doi: 10.1002/ldr.2142

Mulugeta L, Karltun E, Olsson M. 2005. Soil organic matter dynamics after deforestation along a farm field chronosequence in southern highlands of Ethiopia. Agriculture, Ecosystems and Environment 109: 9-19.

Munro RN, Deckers J, Mitiku H, Grove AT, Poesen J, Nyssen J. 2008. Soil landscapes, land cover change and erosion features of the central plateau region of Tigray, Ethiopia: photo-monitoring with an interval of 30 years. Catena 75: 55-64.
Nyssen J, Poesen J, Moeyersons J, Deckers J, Hailu HA. 2004. Human impact on the environment on the Ethiopian and Eritrean highlands - a state of the art. Earth-science reviews 64: 273-320.

Nyssen J, Descheemaeker K, Amanuel Z, Poesen J, Deckers J, M Haile. 2009a. Transhumance in the Tigray highlands (Ethiopia). Mountain Research and Development 29: 255-264.

Nyssen J, Haile M, Naudts J, Munro N, Poesen J, Moeyersons J, Frankl A, Deckers J, Pankhurst R. 2009b. Desertification? Northern Ethiopia rephotographed after 140 years. Science of the total Environment 407: 27492755.

Redoa DJ, Graub HR, Aidea TM, Clark LM. 2012. Asymmetric forest transition driven by the interaction of socioeconomic development and environmental heterogeneity in Central America. PNAS 109: 8839-8844.

Rudel KT, Coomes TO, Moran E, Ac Hard F, Angelsen A, Xu J, Lambin E. 2005. Forest transitions: towards a global understanding of land use change. Global Environmental Change 15: 23-31.

Santos JM, Verheijen FGA, Wahren, FT, Wahren, A, Feger K-H, Bernard-Jannin L, Rial-Rivas ME, Keizer JJ, Nunes, JP. 2013. Soil water repellency dynamics in pine and eucalypt plantations in Portugal - a high-resolution time series. Land Degradation \& Development. doi: 10.1002/ldr.2251

Sloan S. 2008. Reforestation amidst deforestation: simultaneity and succession. Global Environmental Change 18: 425-441.

Tesfay A, Cornelis WM, Nyssen J, Govaerts B, Bauer H, Tewodros G, Tigist O, Raes D, Sayre KD, Mitiku H, Deckers J. 2011. Effects of conservation agriculture on runoff, soil loss and crop yield under rainfed conditions in Tigray, northern Ethiopia. Soil Use and Management 27: 404-414.

Tigist O, Cornelis WM, Verplancke H, Nyssen J, Govaerts B, Mintesinot B, Mitiku H, Deckers J. 2010. Short-term effects of conservation agriculture on vertisols under tef (Eragrostis tef (zucc.) trotter) in the northern Ethiopian highlands. Soil \& Tillage Research 106: 294-302.

Van Rompaey A, Govers G, Puttemans C. 2002. Modeling land use changes and their impact on soil erosion and supply delivery to rivers. Earth Surface Processes and Landforms 27: 48-494.

Woldeamlak B, Stroosnijder L. 2003. Effect of agroecological land use succession on soil properties in Chemoga watershed, Blue Nile Basin, Ethiopia. Geoderma 111: 85-98.

Wright JS, Muller-Landau HC. 2006. The future of tropical forest species. Biotropica 38: 287-301.

Wu JP, Liu ZF, Sun YX, Zhou LX, Lin YB, Fu SB. 2013. Introduced Eucalyptus urophylla plantations change the composition of the soil microbial community in subtropical China. Land Degradation \& Development 24(4): 400-406.

Yitbarek TW, Belliethathan S, Stringer LC. 2012. The onsite cost of gully erosion and cost-benefit of gully rehabilitation: a case study in Ethiopia. Land Degradation \& Development 23(2): 157-166.

Zhou HJ, Van Rompaey A, Wang JA. 2009. Detecting the impact of the 'Grain for Green' program on the mean annual vegetation cover in the Shaanxi province, China using SPOT-VGT NDVI data. Land Use Policy 26: 954-960. 